[Vicino Oriente XXIV (2020), pp. 135-149]

\title{
ARE THE PROVINCIAL CAPITALS OF ĒRĀNŠAHR REALLY PROVINCIAL CAPITALS?
}

\author{
Carlo Giovanni Cereti* - Sapienza University of Rome
}

\begin{abstract}
Šahrestān has often been translated "provincial capital", especially in works dealing with the history of Sasanian Iran. Through a painstaking analysis of Middle Persian occurrences of this word the author shows that it should be translated "city" or "fortified city".
\end{abstract}

Keywords: Sasanian Iran; administrative glyptics; šahrestān; Middle Persian; citadel

\section{1. $\breve{S} A H R E S T \bar{A} N \bar{I} H \bar{A} \bar{I} \bar{E} R \bar{A} N \check{S} A H R$}

In August 1931 Giuseppe Messina, who was then teaching at the Pontifical Biblical Institute of Rome, published from the Nachlass of Joseph Markwart the short geographical treatise commonly known as $\breve{S} a h r e s t \bar{a} n \bar{\imath} h \bar{a} \bar{\imath} \bar{E} r \overline{a n s ̌ a h r}(\breve{S} \bar{E}) .{ }^{1}$ The title of the work is not found in the only known independent codex of this work, MK. In fact, an earlier editor, Jivanji Jamshedji Modi, ${ }^{2}$ chose to call the book Šāhrīha $\bar{l} \bar{E} r \bar{a} n$ and so did Dastur Jamaspji Minocherji Jāmāspasa in his edition of the Pahlavi Texts based on manuscripts MK and JJ. ${ }^{3}$

The first occurrence of $\breve{s}$ ahrestāni ha $\bar{a}$ in the $\breve{S} \bar{E}$ is in paragraph 1, where it is written that the cities $(* \check{s} a h r \bar{a} n$ or $* \check{s} a h r \bar{\imath} h \bar{a})$ in Ērānšahr are described in this memorial. ${ }^{4}$ The spelling $\check{\mathbf{s}}(\mathbf{t})<\mathbf{r}>$ ('n)yh' suggests the possibility of an older *štr' 'n /šahrān/ and though not conclusive, the occurrence in line 12 of the sequence smlknd štr'st'n wiliers ingto form. ${ }^{5}$

where -st- is written above the line also speaks in favor of the older

\footnotetext{
I wish to thank Prof. Almut Hintze of SOAS for having kindly allowed me to use photographs of codex MK The research leading to this paper was done in the framework of the PRIN research project 2017PR34CS "Eranshahr: uomo, ambiente e società nell'Iran arsacide e sasanide. Testimonianze scritte, cultura materiale e società da Arsace a Yazdegard III. Tre casi studio: Pars, Pahlaw e Khuzestan.” For Zoroastrian Middle Persian occurrences see Middle Persian Dictionary Project (ed. Shaul Shaked), last accessed June $15^{\text {th }}, 2020$ http://mpdp.mpdict.com/. A preliminary version of this paper was read at the International Workshop "Sasanian Cities" organized by Dr. Tomoko Morikawa (The University of Tokyo, 19/02/2020) in the context of the MEXT Grant-in-Aid for Scientific Research on Innovative Areas: "The Essence of Urban Civilization".

Markwart 1931

Modi 1898

JamaspAsana 1897-1913, I, 18. The Pahlavi text was also edited by Nyberg (1964-1974, I, 113-117).

MK f. 19r 8-11 š(t)<r>('n)yh' Y BYN zmyk Y 'yl'nštr' <k>rt Y(K)OYMWNyt ywdt ywdt YWM AYK kt'm slhwt'd krt PWN gwk'n QDM ZNE 'dyb'tk'l npšt YKOYMWNyt. Šahrān $\bar{E} r a \bar{n}$ šahr kard ēstēd jūd jūd *ēn kū kadām sarxwadāy kard pad gōgān abar ēn ayādgār nibišt ēstēd "The cities that were built in Ërānšahr, in this memorial it has been written in detail which was the overlord who built each of them". MK has YWM and no variant is reported by JamaspAsana (1897-1913, I, 18) and the reading has generally been accepted by earlier editors. My suggestion is s based on the contents of the text, which seldom mention the year of foundation of each city and on the wording itself.

5 See JamaspAsana 1897-1913, I, 18.
}

ISSN 0393-0300

e-ISSN 2532-5159

Rivista Open Access 
Šahrestān has been translated differently in the two main translations of the $\check{S} \bar{E}$. Markwart $^{6}$ regularly uses "provincial capital", while Daryaee ${ }^{7}$ has chosen to translate it "city". The standard sentence in which the word is found in the $\check{S} \bar{E}$ is "šahrestān $\bar{\imath} \mathrm{X}, \mathrm{Y} \bar{\imath} \mathrm{Z}$ kard":

Š́E 11) Šahrestān ̄̄ marw-rōd wahrām ì yazdegardān kard.

"Wahrām 1 Yazdegardān made the city of Marw-rōd".

Š́E 16) Šahrestān $\bar{\imath}$ kāyēn kay-lohrāsp $\bar{\imath}$ wištāsp pid kard.

"Kay Lohrāsp, the father of Wištāsp, made the city of Kāyēn".

The standard formula knows some variants, adding more details or assigning more than one city to the same founder:

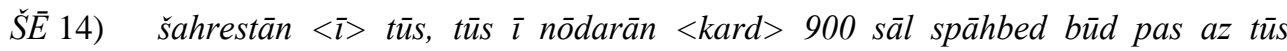
spāhbedīh ō zarēr ud az <zarēr $>\bar{o}$ bastwar ud az bastwar ō karzam.

"Tūs $\overline{1}$ Nōdarān made the city of Tūs, and was Spāhbed for nine hundred years, after Tūs spāhbedship went to Zarēr, and from (Zarēr) to Bastwar, and from Bastwar to Karzam".

ŠE 46) Šahrestān $<\bar{l}>$ ohrmazd-ardaxšīrān ud šahrestān $\bar{l}$ rām-ohrmazd ohrmazd $<\bar{l}>$ $n \bar{e} w-\check{s} \bar{a} b u h r a ̄ n ~ k a r d$.

"Ohrmazd $\overline{1}$ Nēw-Šābuhrān built the cities of Ohrmazd-Ardaxšīrān and RāmOhrmazd".

ŠE 47) Šahrestān $\bar{\imath} \check{s} \bar{u}$ s ud šūstar šīšindōxt zan $\bar{l}$ yazdegard $\bar{l}$ šābuhrān kard čiyōn dōxt $\bar{l}$ rēš-galūta $<\bar{\imath}>$ jahūdagān-šāh mād-iz $\bar{l}$ wahrām $\bar{l}$ gōr būd.

"Šîšindōxt, wife of Yazdegard 1 Šābuhrān made the cities of Šūš and Šūštar, because she was the daughter of the Rēš-Galutā, who is the king of the Jews, and also the mother of Wahrām $\overline{1}$ Gōr".

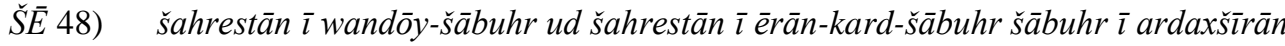
kard $u$-š pēlābād nām nihād.

"Šābuhr $\overline{1}$ Ardaxšīian made the city of Wandōy-Šābuhr and the city of Ērān-kardŠābuhr. He gave a (new) name to Pēlābād".

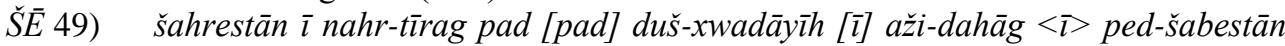

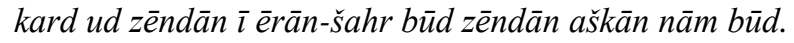

"Ažīdahāg the lord of the harem ${ }^{8}$ made the city of Nahr-Tīrag, and the prison of Ërānšahr was there. The prison's name was Aškān”. 
Examples that do not fit the meaning "Provincial capital":

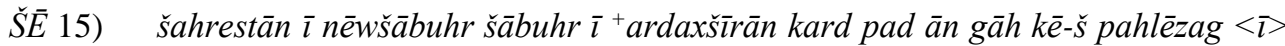
tūr ōzad $u$-š pad ham gyāg šahrestān framūd kardan.

"Šabuhr 1 Ardaxšīān made the city of Nēwšabuhr. When he killed Pahlēzag 1 Tūr, he ordered the city to be made in that very place".

Š́E 17) andar gurgān šahrestān ̄̄ dahestān xwānēnd narsēh ī aškānān kard.

"In Gurgān, Naršēh ī Aškānān made the city that they call Dahestān".

$\check{S} \bar{E}$ 19) Šahrestān panj husraw $\bar{l}$ kawādān $<$ kard $>:{ }^{+}$Kay-husraw-šād $<u d>$ husraw $\bar{\imath}$ mūst-ābād ud wisp-šād-husraw ud hu-bōy-hūsraw *ud šād-farrox-husraw kard $<u d>n \bar{a} m$ nihād" 20) U-š parisp-ē kē 180 frasang drahnāy ud 205 šāh ārešn bālāy $<u d>100$ ud 80 dar $<u d>k \bar{s} s ̌ k$ [ud] dastgird andar framūd $<k a>r d a n$.

"Husraw 1 Kawādān made five cities: Kay-husraw-šād, Husraw 1 Mūstabād, Wispšād-Husraw, Hu-bōy-Husraw and Šād-farrox-Husraw and gave (them their) names. He ordered that a wall one hundred and eighty parasang long and twentyfive royal cubits high be built, and inside (the wall) one hundred and eighty pavilions and an estate".

ŠE 28) 21 šahrestān $\bar{\imath}$ andar padišxwārgar kard ēstēd az armāyūl enyā az framān $\langle\bar{\imath}\rangle\langle\bar{\imath}\rangle$

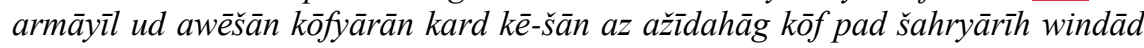
$\bar{e} s t a \bar{d}$.

"The twenty-one cities that were made in Padišxwārgar by Armāyīl or by the order of Armāyîl, and those mountaineers made (these cities), since the dominion of the mountains was entrusted to them by Ažīdahāg".

$\check{S} \bar{E}$ 32) 9 šahrestān andar zamīg $<\bar{\imath}>$ gazīrag kard ēstēd ud āmtūs ud kēsar brādar-zād kard.

"Nine cities were made in the land of Jazīra, *Antoninus" and (?) the nephew of the Caesar made (them)".

ŠE 33) 24 šahrestān andar zamīg $\langle\bar{\imath}\rangle \check{s} \bar{a} m<$ ud> yaman ud frīgā ud kūfah ud makkah ud madīnag gāh kard ēstēd ast šāhān šāh ast kēsar.

"Twenty-four cities were made in the lands of Syria, Yaman, Africa, Kufa, Mecca and Medina, some by the King of Kings, some by the Caesar".

$\check{S} \bar{E}$ 35) $\quad \check{S}$ ahrestān $<\bar{l}>$ raxwat rahām $\bar{l}$ gōdarzān kard pad ān gāh ka-š aspwarz-nar $\bar{\imath} t \bar{u} r$ $\bar{o} z a d$ u-š yabbu-xāgān az ānōh stō be kard.

"Rahām $\overline{1}$ Gōdarzān made the city of Raxwat when he killed Aspwarz-nar $\overline{1}$ Tūr, He defeated the Yabbū-Xāgān from there”.

The description of the Region of Ādūrbādagān contained in the final part of the Šahrestānīhā $\bar{\imath} \bar{E} r \bar{a} n s ̌ a h r$ is incoherent; interestingly, however, two šahrestāns are mentioned for Ādūrbādagān:

9 Markwart $(1931,82)$ is probably right in identifying this character with Lucius Ceionius Commodus Verus Armeniacus, who in 162-166 led a military campaign against the Parthian Empire. However, the name renders *Antoninus, and can thus be associated with any of the Emperors of the Antonine dynasty. 


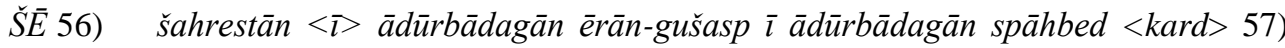

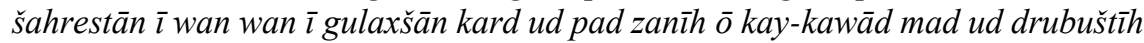
$\bar{\imath}$ arwandāsp ${ }^{10}$ tūr $\bar{\imath}$ brādarōš $\bar{\imath}$ karb pad jādūgīh kard pānāgīh $\bar{\imath}$ gyān xwēš rāy. 58) pad kust $\langle\bar{l}\rangle$ ādūrbādagān šahrestān $\bar{l}$ ganzag frāsiyāk $\langle\bar{l}\rangle$ tūr kard. 59) šahrestān $\bar{\imath} \bar{a} m \bar{o}{ }^{+}{ }^{+}$andīg $\bar{\imath}$ purr-marg kard. zardušt $\bar{\imath}$ spitāmān az ān šahrestān ${ }^{11}$ būd. 60) šahrestān ī baydād abū-jafar čiyōn-šān abū-dawānīg xwānd kard.

“56) Ērān-Gušasp, Spāhbed of Ādūrbādagān, made the city of Ādūrbādagān. 57) Wan $\overline{1}$ Gulaxšān made the city of Wan and it came to Kay-Kawād through marriage, and Tūr $\overline{1}$ Brādarōš by magic (built) the Fortress of Arwandāsp, (for) the protection of his soul. 58) In the Region of Ādūrbādagān, Frāsiyāk ī Tūr made the city of Ganzak. 59) The heretic full of death made the city of Āmōy, Zardušt $\overline{1}$ Spitāmān was from that city. 60) The city of Baghdad was built by Abū-Jafar, whom they call Abū-Dawānīg, (He) who stands in victory". ${ }^{12}$

Summing up, many of the occurrences in the ŠE suggest a meaning in the semantic range of "city", "built area", in a few cases "fortified city". Turning now to other Pahlavi texts, let us see what the evidence is.

\section{OTHER MidDLE PERSIAN TEXTS BELONGING TO THE ZOROASTRIAN TRADITION}

\subsection{Bundahišn}

The two examples taken from the Bundahišn occur one in chapter nine, describing the nature and whereabouts of known mountains, and the other in chapter thirty-two, on the mansions of the Kayāns. The second passage falls between a first list of abodes made by Jam, Frēdōn, Kayōs, Dahāg, Siyāvaxš and Frāsyāb, and the more detailed description of these manors. Both passages show a hierarchy between $\breve{s} a h r$ and $\breve{s} a h r e s t a \bar{n}$, the latter being used in a meaning that does not seem to be that of provincial capital.

Bd. 9.23 bagēer kōf ān $\bar{l}$ frāsyāa $\bar{\imath}$ tūr pad drubuštīh dāšt $u$-š ān mān andarōn kard $u$-š imrōz šahr ̄̄ rām-pērōz ud bēwar šahrestān abar abgand estēd.

"Bagēr kōf is the one which the Tūr Frāsyāb held as fortress, he made that mansion inside it. In these days the province of Rām-Pērōz and a myriad cities are strewn out on it".

${ }^{13}$ Bd. 32.9 èn ān ī pad abd-kardīh kard èstēd tā abārīg was šahr ud šahrestānīhā ud mānīhā kard hēnd kē gōkān dagrand. ${ }^{14}$

"These are those which have been made through miracle-working, while they made (also) many other provinces, cities and mansions, whose details would be long (to tell)".

10 Probably *Drubušt $\bar{l}$ Arwandāsp the "Fortress of Arwandāsp". Interestingly, here as in a passage of the Dēnkard (see infra), šahrestān comes together with drubušt, in a meaning close to the one known in New Persian of "fortified city".

11 Here šahrestān is written with the heterogram MDYNA.

12 For a partially different reading of $\$ 60$ see De Jong 2008, 55-57.

13 See Cereti 2004, 25, 26, 29, with a slightly different translation; cf. Pakzad 2005, 133.

14 Pakzad 2005, 360. 


\subsection{Dēnkard 6}

Dk. 6.234 u-šān èn-iz ōwōn dāšt ku harw čée *ka andar ān tis ēstēd ì dahibed pad *nē kardan framān abar dād ēstēd, ka rēš awiš rasēd ōwōn *tōzēd čiyōn kē az dušmān anabìm ud pad kām $\bar{\imath}$ xwēš nē $\bar{o}$ *šahrestān $\bar{\imath}$ diz $\bar{l}$ drubušt $\bar{l}$ ābādān bē $\bar{o}$ diz $\bar{l}$ kahwan $\bar{\imath}$ awērān kē kas andar nēst šawēd ud mìrēd ayāb zad bawēd pad margīh ud zadan $\bar{\imath}$ xwēš xwad tōzēd.

"They held this too: Whenever one perseveres in doing something which the ruler has issued and order not to do, he pays penance for that when suffering comes upon him in the same manner as a man who is unafraid of the enemy and by his own decision goes not to a fortified and populous castle town but to an old and deserted castle in which there is no one and he is killed or beaten. He pays penance (for his action) by being killed or beaten". ${ }^{15}$

\subsection{Ayādgar $\overline{1}$ Jāmāspīg}

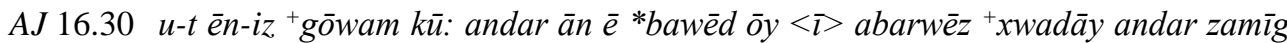
*ī hrōm was šahr ud was šahrestān gīrēd ud was ${ }^{+} x w \bar{a} s t a g$ pad $\bar{e} w$-bār az zamīg $<\bar{\imath}>$ hrōm āwarēd.

"And this also I am going to tell you: In that <period> there will be one <man>, that Victorious king will conquer many provinces and many fortified cities in the land of Hrōm and will at once bring (back) from the land of Hrōm much property". ${ }^{16}$

AJ A19 šązdahami ịn ku var *hašt ku pae sīštąi ba *vas $\bar{\partial} \underline{t} * u *$ zrahe šăheraštąn $\bar{a} v a$ ba bar àt hamā sīštąni pur āva bab jọt. ${ }^{17}$

The sixteenth is this that: there is a lake (var) that (is) in Sistan, it will open and the lake (zrahe) of the town $\backslash$ manor ${ }^{18}$ will let water flow and the whole Sistan will be full of water".

\subsection{Kārnāmag $\overline{1}$ Ardaxšīr 1 Pābagān}

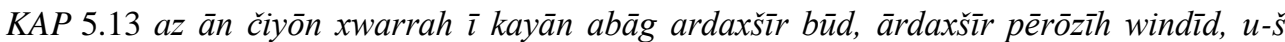
ardawān ōzad, ud hāmōyēn xīr ud xwāstag $\bar{o}$ dāst $\bar{l}$ ardaxš̄ir mad, ud duxt $\bar{\imath}$ ardawān pad zan̄̄h kard, abāz ō pārs mad, šahrestān $\bar{\imath}$ ardaš̄ir-xwarrah xwānēnd kard, ud ān $<_{\bar{l}}>$ wuzurg kand, āb čahār jōy az-iš āwurd, ud ātax ̌̌ $<\bar{o}>$ war nišāst,

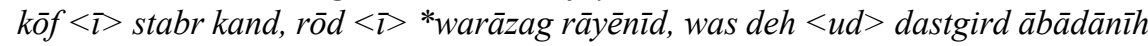
kard, was ātax ̌̌ $<\bar{l}>$ wahrām anōh framūd nišāstan.

"Parce que la Fortune des Kavis était avec Ardashir, il obtint la victoire, il tua Artaban. Tous ses biens et ses richesses tombèrent aux mains d'Ardashir, et il prit sa fille pour femme. Étant revenu au Fârs, il bâtit la ville qu'on appelle Ardashir-

15 Shaked 1979, 90-91. The expression *šahrestān $\bar{l}$ dēz $\bar{l}$ drubušt $\bar{~}$ ābādān clearly defines a fortified and prosperous city.

16 See further Agostini 2013, 80-81, 112,190; the text is taken from the Pahlavi version of chapter sixteen of this multilayer text.

17 See Agostini 2013, 169-170, who prefers to translate "Le seizième est celui-ci : les deux lacs qui sont dans le Sīstān s'ouvriront et le lac de la province portera de l'eau et tout le Sīstān sera inondé", changing the second $k u$ in $d u$.

18 Possibly the reference is to the Hāmun lake, at the center of which stands Kuh-e Khª̄ja. 
khwarrah («Fortune d'Ardashir»), il fit creuser un grand lac d'où furent dérivés quatre canaux, il établit un feu près du lac, il fit creuser une grosse montagne et y fit passer la rivière Warâzag, il mit en valeur beaucoup de villages et de domaines et il ordonna d'établir là beaucoup de Feux Wahrām". ${ }^{19}$

\subsection{Kārnāmag $\overline{1}$ Ardaxšìr 1 Pābagān}

11.16 u-š ham gyāg šahrestān-ēe, wālaxš-šābuhr xwānend, framūd kardan, ud dah ātax ̌̌ $<_{i}>$ wahrām ānōh nišāst, ud was xīr ud xwāstag $\bar{o}$ dar $<\bar{\imath}>\bar{a} d u r \bar{a} n-\check{s} \bar{a} h$ frestīd, ud was kār ud kirbag framūd rāyēnīdan.

"Et en ce même lieu il ordonna de bâtir la ville qu'on appelle Wālaxš-Shâpur, et il y établit dix féaux Wahrâm, et il envoya beaucoup de biens et de richesses au palais du Roi des Feux, et il ordonna d'organiser beaucoup d'actions pieuses". ${ }^{20}$

\subsection{Gujastag Abāliš}

GA 6.8 Dādestān ì èn ōwōn hōmanāg čiyōn šahrestān-ēw hamāg pēšag andar hēnd āsnkar ud kaf̌̃-kar ud drōd-kar ud darzīg ... ${ }^{21}$

"The case is like a city in which there are all the trades: a blacksmith, a shoemaker, a carpenter, and a tailor...".22

GA $6.15<$ pad> homānāg dušman-ēw ka ō šahrestān-ēw mad 16) ud agar-šān šahrdār ì ān

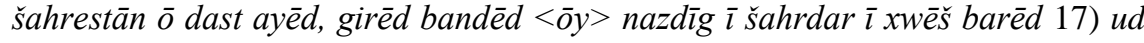
agar-šān šahrdār $\bar{l} \bar{a} n \bar{l}$ šahrestān griftan nē tuwān 18) ān-ummēeīhā pad ham šahrestān andar šāwēd, 19) ud šahrestān awērān kunēd. ${ }^{23}$

"It is like an enemy who has come into the city. If the king of that city falls into the hands of the enemy, the enemy seizes him and binds him and brings him into the presence of his own king. If they cannot seize the king of that country, they enter the city at an unexpected (?) place and lay waste the city". ${ }^{24}$

\section{7. Šāyast nē-Šāyast}

Šn 2.74 dar-ē kē nasā padiš paykōbēd pad dar ì dēh ud šahrestān ham-dādestān būd hēnd ku pad ham-kār be hilišn, pad dar ì bērōn jud-dādestān hēnd...

"[As to] a gate on which nasāk impinges: about the gate of a village and a city they have been of the same opinion, that it is to be left for the same use; about the outermost gate they have been of different opinions...". 25

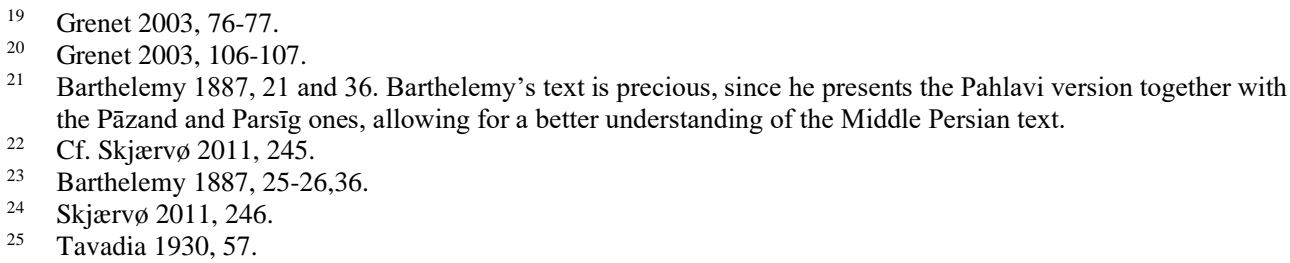




\subsection{Yōišt 1 Friyān}

YF az šahrestān bhrōč.

"From the town of Broach". ${ }^{26}$

\subsection{Pahlavi commentary to Widēwdād}

Interesting is also the Pahlavi commentary to Widēwdād I.14, describing the fourteenth of the lands created by Ahura Mazda, Varəna čaAru-gaoša 27 "having four ears" possibly in the meaning "four-squared".

Wd. 1.17.5 čahārdahom az gyāgān ud rōstāgān ā-m pahlom frāz-brēhēnīd man kē ohrmazd (hom) waren $\bar{\imath} 4$-gōš *padišxwārgar *dēlam. ${ }^{28}$ ast kē kērmān gōwēd. u-š 4-gōš̄ih $\bar{e} n$ kū rāh 4 andar be èstēd. ast kēe èdōn gōwēd ay šahrestān[īh] dar čahār ast.

"Fourth amongst places and villages that I then created excellent - I who am Ohrmazd - (is) the four-cornered Waren - Padišxwārgar, Dēlam - one says Kērmān, its fourcornerness means that there were four roads inside (it), one says that is: the city has four doors". 29

Finally, these few passages taken from other texts belonging to Pahlavi literature show meanings that range from "town" to "city" "fortified and prosperous city" closely matching what one can observe in the ŠSE.

\section{INSCRIPTIONAL MIDDLE PERSIAN}

\subsection{Early Sasanian inscriptions}

Šahrestān occurs also in a limited number of passages found in inscriptions dating to the early Sasanian centuries, namely in the long trilingual inscription that Šâbuhr ordered to be engraved on the walls of the Achaemenid Ka'aba-e Zartošt, in a long passage found in Kerdīr's inscriptions and in a short and only very partially preserved passage from Narseh's inscription at Paikuli. ${ }^{30}$ Interestingly, both Šābuhr and Kerdīr use šahrestān to describe cities, not necessarily provincial capitals, that were conquered by the Persian army, while Narseh employs it to describe the otherwise unknown city where he held court.

26 In YF šahrestān occurs in the colophon, referring to the Indian town Broach in Gujarat, Haug - West 1872,246

27 On which see Gnoli 1980, 47-50.

28 Or possibly salm, kērm.

29 Jamasp 1907, 17.

30 Gignoux 1971, 34 and 53. 
ŠKZ ${ }^{31} \quad \S 10 \ldots$ ud grift pad hō è(w) yāwar až frōmāyīn šahr, diz ud šahrestān ${ }^{32} \S 11$

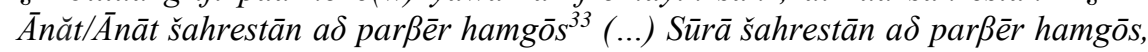

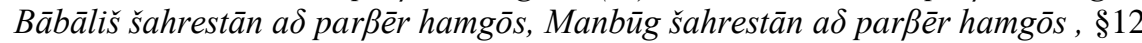

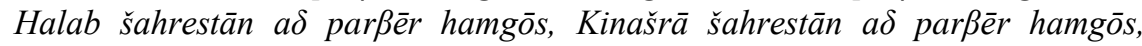
Apōmiyā šahrestān a $\delta$ parß̄er hamgōs, Refauiyos šahrestān a $\delta$ parßēr hamgōs, Zōmā šahrestān a $\delta$ parßēr hamgōs, Umā šahrestān a $\delta$ parßēer hamgōs, § 13 Gindaros šahrestān a $\delta$ parßēr hamgōs, Armenāž šahrestān a $\delta$ parßēr hamgōs,

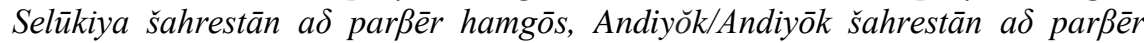

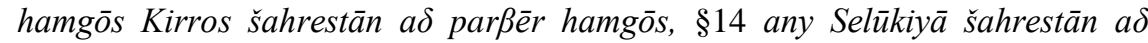
parßēr hamgōs, Alesandariyā šahrestān a $\delta$ parßēr hamgōs, Nīkopolos šahrestān

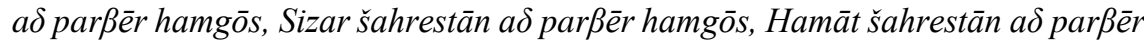

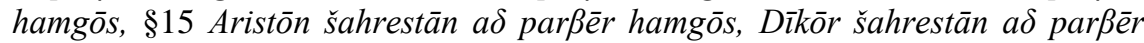

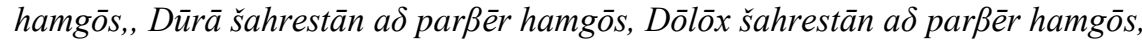
Kirkisiyā šahrestān a $\delta$ parßēer hamgōs, Garmaniyōs šahrestān a $\delta$ parßēr hamgōs,

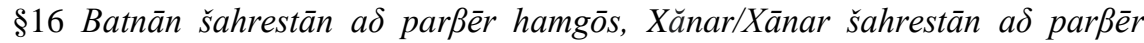
hamgōs, pad Kap(p)ōdakiyā Sātal šahrestān a j parßēr hamgōs, Domān šahrestān

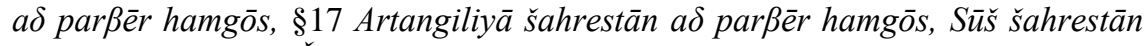

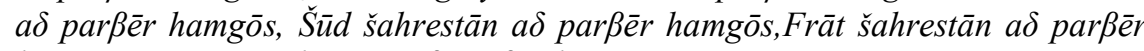
hamgōs. Hamsāg šahrestān a parßēr hamgōs 37. "§ 10 Und (es wurden) genommen (= erobert) bei jener einen Gelegenheit aus dem Reich der Römer die (folgenden) Festungen und Städte: §11 Ānăth/Ānāth, die Stadt mit samt die umliegenden Gebiet(...) Sura, Barbalissos, Hierapolis, §12 Berrhoia, Khalkis, Apameia, Rhephaneia, Zeugma, Urima, §13 Gindaros, (L)armenaza, Seleukeia, Antiokheia, Kyrrhos $\$ 14$ ein anderes Seleukeia, Alexandretta, Nikopolis, Sinzara, Hamāth, § 15 Aristhia, Dikhōr, Dura, Dolikhē, Kirkēsion, Germanikeia, §16 Bathnai, Khănar/Khānar; und in Kappadokien Satala, Domana, §17 Artangilla (?), Suisa, Suida, Phreata. Gesamtzahl: 37 Städte mitsamt dem umliegenden Gebiet”.

$\mathrm{KNRm}^{34} \quad \S 15$ u-m pad̄̄z Anērānšahr ādur ud mowmard čē pad šahr ī anērān bud kū asp ud mard $\bar{\imath}$ šāhān šāh rasīd andiyōk šahrestān ud sūriyā šahr ud čē abar sūryā nahang. *Tersōs šahrestān ud kilikiyā šahr ud čē abar kilikiyā nahang. Kēsariyā šahrestān ud kapōdakiyā šahr ud čè abar kapōdikiyā nahang tā frāz $\bar{o}{ }^{*}$ Grāykiyā šahr ud Arman šahr ud Wiruzān ud Alān ud Balāsagān tā frāz ō Alānān dar Šābuhr šāhān šāh pad asp ud mard $\bar{\imath} x w e \bar{s}$ zad $u$-š wardag ud ādur sōxt ud awērān kard.

" $\$ 15$ And also in the land of Aneran, the fires and magians which were in the land of Aneran where the horses and men of the king of kings reached - The city of Antioch and the land of Syria, which is attached to the province of Syria, the city of Tarsos and the land of Cilicia and what is attached to the province of Cilicia, the city of Caesarea and the land of Cappadocia and what is attached to the province of Cappadocia, up to the land of Graecia (= Pontus ?) and the land of

\footnotetext{
Huyse 1999, I, 29-33. The Parthian version is given, since the Middle Persian one presents large lacunae.

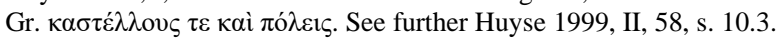

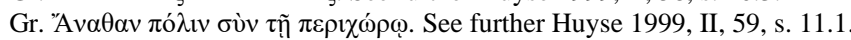

MacKenzie 1989, 55; the same passage occurs in KSM and KKZ, see Gignoux 1991, 62-63.
} 
Armenia and Iberia (= Georgia) and Albania and Balasagan up to the gate of the Alans, Shapur, king of kings, with his horses conquered them all...".35

$\mathrm{NPai}^{36} \S 59 \mathrm{MP}\left[\mathrm{pr}^{\prime} \mathrm{c} \mathrm{OL}\right.$ ? štrdst'n ZY wlhl'mš?] hpwuhry

Pth. [prhš OL? wryhrmšhypwhr]y hštrst'n

" $<$ Forth to $>$ the city $<$ Wahrām-Š $>$ ābuhr".

\subsection{Sasanian glyptics}

Šahrestān is well attested in primary sources dating to the late Sasanian period, more specifically in administrative glyptics. ${ }^{37}$ Remarkably, the only offices attested are the mowūh "Office of the magi" and the naxwar, the latter being attested for the province of Frāx-karPērōz in Sistan. From a formal point of view, we can distinguish a formula Weh-Ardaš̄ir šahrestān mowūh, Weh-Ardašīr "Office of the magi, city of Weh-Ardašīr, (province) WehArdašīr", where the name of the city and that of the province may or may not be identical (A) and a second type askēn-rōd mowūh, hamadān kust $\bar{l}$ šahrestān "Office of the magi of Askēnrōd, Hamadān district of the city”.

A)

ATs4 weh-ardašì šahrestān mowūh, weh-ardašìr.

ATs31 tasōg $\bar{l}$ zarang šahrestān mowūh, zarang šahrestān.

ATb76a, ATb77a weh-andiyōk-šābuhr šahrestān mowūh, weh-andiyōk-šabuhr.

ATb78a zarang šahrestān mowūh, zarang.

ATb 290a tēsfōn šahrestān mowūh, husraw-šād-kawād.

ATb306a ....̌̌̆ahrestān mowūh, èrān-xwarrah...

ATb355a ganzag šahrestān mowūh, ādurbādagān.

ATb 900a rām šahrestān mowūh, ray.

B)

ATs10 āluh (?) mowūh frāx-kar-pērōz kust ī šahrestān. ATs24 sād kust $\bar{l}$ āb mowūh, hamadān kust $\bar{\imath}$ šahrestān.

ATs29 zar ... mowūh, hamadān kust ì šahrestān.

ATb285a, ATb287a, ATb893a askēn-rōd mowūh, hamadān kust ī šahrestān.

ATb 286a, ATb880a, ATb883a, ATb923a askēn-rōd mowūh, hamadān kust ī šahrestān.

ATb288a, ATb922a hamadān-frāx-kar mowūh, hamādan kust ì šahrestān.

ATb339a anbōr-bārzand ${ }^{38}$ mowūh, frāx-kar-pērōz kust ì šahrestān.

ATB845a, ATb846a, ATb911a, ATb912a, ATb913a, ATb914a kust ī šahrestān, frāx-karpērōz kust $\bar{\imath}$ šahrestān naxwar.

ATb864a ...kust $\bar{\imath}(\check{s} a h r e s t a ̄ n) ~ m o w \bar{h}$...

MacKenzie 1989, 58

36 Both the Middle Persian and Parthian versions present vast lacunae, see Humbach - Skjærvø 1979-1983, vol. $3.1,54$. On the identification of the city, otherwise unknown in primary sources, see Humbach - Skjærv $\varnothing 1979$ 1983, vol. 3.2, 83, 94

37 Numbering of seals and sealings according to Gyselen 2019a. See Gyselen 2019a, 328-329; 2019b, 163-164

38 Gyselen 2019a, 434 [']nbwly-b[y]lcndy, anbōr-birzand. 
In her important work on Sasanian glyptics, Rika Gyselen ${ }^{39}$ regularly translates šahrestān "capitale provinciale". However, the French author reports some occurrences where cities that are known to have been provincial capitals are not accompanied by šahrestān, such are $N \bar{e} w$-Šābuhr and $G \overline{o r} r .40$

On a more general note, in administrative glyptics the term šahrestān qualifies only a very limited number of Sasanian towns; in fact we know only: Ērān-xwarrah-Šābuhr šahrestān (one mowūh seat?) Weh-Andiyōk-Šābuhr šahrestān (one mōwuh seat); WehArdaxšīr šahrestān (one mowūh seat) Zarang šahrestān (two mōwuh seats) Ganzag šahrestān (one mowūh seat) in Ādurbadagān, Tēsfōn šahrestān (one mowūh seat) in Husraw-šādKawād, and Rām(-Pērōz) šāhrestān (one mowūh seat) in Ray. The locution Kust $\bar{l}$ šahrestān is attested only for Frāx-kar-Pērōz (two mowūh seats and one naxwar) and Hamadān (four mowūh seats).

\section{MANichaeAn MidDle PERSiAn TEXTS}

According to Durkin Meisterernst's dictionary of Manichaean Middle Persian and Parthian šhryst'n occurs in the possible meanings of "province, provincial capital, city". ${ }^{41}$ However, the only one to translate it "provincial capital" was Henning in Mitteliranische Manichaica ii and iii for Holwān and Bēlābād and he himself chose to use "city" in a later work. ${ }^{42}$ The occurrences are the following:

MMii, RI $35^{43}$

34) dwdy k' prystgrwšn 35) 'ndr hlwn šhryst'n 36) bwd.

"Als dann der Gesandte des Lichts in der Provinzhauptstadt Holvān war".

MMiii, C $26^{44}$

23) $\quad . . p d c f^{\prime} r$ sxt šhryyw $r$ r] 24) $m$ ' $\underline{h}$ šhrywr rwc dwšmbt 25) [ 'wd 'y]wnds jm 'n 'ndr 'wyst'm 26) 'y hwjyst'n u šhryst'n 27) cy byl'b'd.

“...am vierten des Monats Scharewar, am Tage Schahrewar, Montags, zur elften Stunde, in der Provinz Chuzistan und in der Provinzhauptstadt Belabad".

Kaw A $\left.106^{45} 106\right) \quad \ldots$ 'c šhryst'n šhryst' $[n \ldots$

“...from each city ...".

9 Gyselen 2019a.

40 Gyselen 2019a, 24-25: “On peut remarquer que le nom de Nēw-Šābuhr, habituellement considéré comme capitale provinciale d'Abaršahr, n'est pas suivi de la spécification šahrestān «capitale provinciale». On peut évidemment évoquer un oubli de la part du graveur ou la manque de place sur le sceau, sans pour autant évincer d'autres explications. D'ailleurs, ce n'est pas le seul cas où le terme šahrestān n'apparaît pas alors qu'on s'y attend - peut-être à tort. On peut citer comme parallèles Gōr / Ardašīr-xwarrah (ATs12, ATb95a), Nēmāwand / Māh-kust-ī-Nēmāwand (ATb205a). Aussi dans ces cas Gōr et Nēmāwand sont censés être des capitales provinciales et on serait attendu à les trouver sous la forme Gōr-šahrestān et Nēmāwand-Sahrestān". See also Gyselen 2019a, 41.

41 Durkin-Meisterernst 2004, 318.

$42 \quad$ Henning 1943.

43 MP; Andreas - Henning 1933, 11 [199], original transliteration in Hebrew.

44 Pth.; Andreas - Henning 1934, 16 [288].

45 MP; Henning 1943, 58 and 62 [120 and 125]. 


\section{A.R. VIIa/ $14 \mathrm{~b}^{46}$ \\ 14b ubwd ('y)y wygndg pd hrwyn šhryst t’n. \\ "Thou hast suffered ravage among all cities".}

KPT $804^{47}$

803) c'wn n'mg pd tyr ['w] 804) šhryst'n whynd.

"Wie man einen Brief mit einem Pfeil [in] eine Stadt schießt".

MKG $105^{48}$

104) $\quad[p](\check{s} \check{s}) w d$ 'hym [...] 105) $[\check{s}](h) r y s[t ' n$...]

MKG $656^{49}$

"[Da]nach ging ich [...St]adt...".

654) ...kw kd 'm 'h 655) pydr 'c hyndwg'n 'gd 'wd 656) 'w ryw'rdxšyhr šhryst'n 657) gd. MKG $667^{50}$

"...als unser Vater aus Indien kam und in die Stadt Rēw-Ardaxšihr gelangte".

665) ...'dyn kd 666) qyrbkr bdyg y'wr (')[n](dr) 667) ryw'rx̌̌yr š(hry)st'n bwd. MKG $981^{51}$

"...Als dann der Wohltäter ein zweites Mal (in) der Stadt Rēw-Ardaxšihr war".

979) $\quad . . k w(')[2-4]$ 980) 'nd(r) 'wh(rmyzd) 981) 'rdxšyh(r šhr)yst['n] 982) [p](t) m'nyst'n (qdg) 983) ['gw]št (?)

“...daß [...] in der Stadt Ohrmezd-Ardaxšihr war er [i]m Klostergebäude [verbor]gen".

MKG $1897^{52}$

1896) byd kd fryštg ['](ndr) wyh( r)[dhšyr] (?) 1897) šhryst'n (b) [wd ...].

"Als dann der Apostel (in) der Stadt Weh-Ar[dahšīr] w[ar ...]".

CPar $147^{53}$

145) (q)['w'n (?)] 146) 'st pt bwn (c)[y smyr](w) (?) qwf 'w 147) hwr's'n 'rg (̌s)[wynd (?) ']w ̌s (h)rystn.

"<Die Rede> [von den Giganten ??] ist am Fuße des [Sumer](u?)-Berges zur Ostseite (sie gehen ? zur) Stadt".

\footnotetext{
Pth.; Boyce 1954, 166-167.

MP; Sundermann 1973, 44

Pth.; Sundermann 1981, 23

9 Pth.; Sundermann 1981, 56

Pth.; Sundermann 1981, 57

Pth.; Sundermann 1981, 70.

Pth.; Sundermann 1981, 116.

3 Pth.; Colditz 1987, 298-299.
} 


\section{CONCLUSION}

Summing up, Pahlavi literature uses the term šahrestān to indicate a city or town, and there is some evidence to show that at least in some of the occurrences the reference is to a fortified city. More specifically, the author of the $\check{S} \bar{E}$ widely employs this word to define cities, also when talking in rather generic terms $(\S \S 28,32,33)$ and once applies it to what seem to be the five inhabited areas of a yet unidentified royal compound ( $§ 19)$. In primary sources dating from the $3^{\text {rd }}$ century šahrestān is mainly applied to the cities that were conquered by the triumphing armies of Šăbuhr I in his campaign against the Roman Empire; some, but by no means all of these cities were provincial capitals. The evidence provided by Narseh's inscription points to the possibility of using the term also for Sasanian cities, indeed for the one where he held court, but the passage is extremely corrupt. In administrative glyptics šahrestān is employed to describe a city, or an inhabited area, but we have no proof that it is specifically used to design a provincial capital, since we know cases of cities that definitely were provincial capitals but were not called šahrestān on seals. In Manichaean texts šahrestān has the meaning of city, large town, while "provincial capital" would only fit some of the occurrences. In fact, Henning translated "Provinzhauptstadt" in his earlier works, ${ }^{54}$ where the word respectively qualified the two large cities Holvān and Bēlābād, then shifted to "city" in the edition of the Book of Giants, ${ }^{55}$ a meaning that was kept by Boyce, Sundermann and Colditz. ${ }^{56}$ Finally, I believe that šahrestān should be translate by "city", possibly "fortified city", later even "town" or densely populated area; perhaps the original meaning was "inner city" or even "citadel". In fact, the best definition of the term in Middle Persian is the passage from the sixth book of the Dēnkard: *šahrestān $\bar{\imath}$ diz $\bar{\imath}$ drubušt $\bar{l}$ àbādān "šahrestān, a castle and fortress which is also an inhabited place" i.e. "a strongly fortified and populous town", a meaning that includes but is not limited to provincial capitals.

\section{ABBREVIATIONS}

A.R. Angad Rōšnān see Boyce 1954, with strophes as assigned there.

Bd. Bundahišn see Pakzad 2005.

Dk. $\quad$ Dēnkard book 6, see Shaked 1979.

CPar Colditz 1987, with line numbering as assigned there.

GA Gujastag Abālišs, see Barthelemy 1887 and Skjærvø 2011.

KAP Kārnāmag $\bar{\imath}$ Ardaxš̌̀ir $\bar{\imath}$ Pābagān, see Grenet 2003.

Kaw Book of Giants, see Henning 1943 with letters and line numbering as assigned there.

KNRm Kerdir's inscription at Naqsh-e Rostam, see MacKenzie 1989, cf. Gignoux 1991.

KPT Sundermann 1973, with line numbering as assigned there.

MKG Sundermann 1981, with line numbering as assigned there.

MMii Andreas - Henning 1933 with letters and line numbering as assigned there.

MMiii Andreas - Henning 1934 with letters and line numbering as assigned there.

NPai Narseh's inscription at Paikuli, see Humbach - Skjærvø 1979-1983.

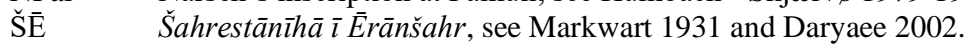

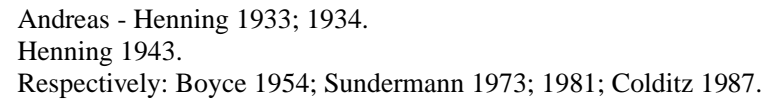


ŠKZ Šābuhr I's inscription on the Ka'aba-e Zartosht, see Huyse 1999.

ŠnŠ $\quad \check{S} \bar{a}$ ayast $n \bar{e}$-Šāyast, see Tavadia 1930.

Wd. Widēwdād, see Jamasp 1907.

YF Yōišt ī Friyān, see Haug - West 1872

\section{REFERENCES}

AGostini, D.

2013 Ayādgār $\bar{\imath} J \bar{a} m \bar{a} s p \bar{\imath} g$. Un texte eschatologique zoroastrien (Biblica et Orientalia 50), Rome 2013.

ANDREAS, F.C. - HENNING, W.B.

1933 Mitteliranische Manichaica aus Chinesisch-Turkestan II: Sitzungsberichte der preussischen Akademie der Wissenschaften (1933), pp. 292-363. Reprinted: W.B. HENNING, Selected Papers I (Acta Iranica 14), Téhéran-Liège 1977, pp. 191-260.

1934 Mitteliranische Manichaica aus Chinesisch-Turkestan III: Sitzungsberichte der preussischen Akademie der Wissenschaften (1934), pp. 846-912. Reprinted: W.B. HENNING, Selected Papers I (Acta Iranica 14), Téhéran-Liège 1977, pp. 275-339.

BARTHELEMY, A.

1887 Gujastak Abalish. Relation d'une conférence théologique présidée par le Calife Mâmoun, Paris 1887.

BOyCE, $\mathrm{M}$

1954 The Manichaean hymn-cycles in Parthian (London Oriental Series 3), London 1954.

CERETI, C.G

2004 Middle Persian Geographic Literature: the Case of the Bundahišn: R. GYSELEN (ed.), Contributions à l'histoire et la géographie historique de l'empire sassanide (Res Orientales XVI), Bures-sur-Yvette 2004, pp. 11-36.

COLDITZ, I.

1987 Bruchstücke manichäisch-partischer Parabelsammlungen: Altorientalische Forschungen 14 (1987), pp. 274-313.

DARYAEE, T.

2002 Šahrestānīhā $\bar{\imath}$ Ērānšahr. A Middle Persian Text on Late Antique Geography, Epic and DE JONG, A.

2008 The Beginning and the End of the Šahrestānīhā $\overline{1}$ Ẽrānšahr: Bulletin of the School of Oriental and African Studies 71.1 (2008), pp. 53-58.

DHABHAR, B.N.

1949 Pahlavi Yasna and Visperad, Bombay 1949.

DURKIN-MEISTERERNST, D.

2004 Dictionary of Manichaean Middle Persian and Parthian (Corpus Fontium Manicheorum, Dictionary of Manichaean Texts, Vol. III, Pt. 1), Turnhout 2004

Gignoux, PH.

1971 Glossaire des Inscriptions Pehlevies et Parthes (Corpus Inscriptionum Iranicarum, Supplementary Series I), London 1971

1991 Les quatre inscriptions du mage Kirdìr. Textes et concordances (Studia Iranica, Cahier 9), Paris 1991.

GYSELEN, R.

2019a La géographie administrative de l'Empire Sassanide. Les témoignages épigraphiques en moyen-perse (Res Orientales XXV), Bures-sur-Yvette 2019. 
2019b Les données de géographie administrative dans le Šahrestānīhā $\overline{1}$ Ēān: une réévaluation : A. Hintze - D. Durkin-Meisterernst - C. NAumann (eds), A Thousand Judgements. GNOLI, GH. Festschrift für Maria Macuch, Wiesbaden 2019, pp. 161-174.

1980 Zoroaster's Time and Homeland. A Study on the Origins of Mazdeism and Related Problems (Series Minor VII), Naples 1980.

GRENET, F.

2003 La geste d'Ardashir fils de Pâbag. Kārnāmag ì Ardaxšēè ī Pābagān, Die 2003.

HENNING, W.B.

1943 The Book of the Giants: Bulletin of the School of Oriental and African Studies 11 (1943), pp. 52-74. Reprinted: W.B. HenNING, Selected Papers II (Acta Iranica 15), Téhéran-Liège 1977, pp. 115-137.

HAUG, M. - WeSt, E.W.

1872 The Book of Arda Wiraf, Bombay - London 1872.

HuMBACH, H. - SKJERV Ø, P.O.

1979-1983 The Sassanian Inscription of Paikuli, 3 vols, Wiesbaden 1978-1983.

HuYse, PH.

1999 Die dreisprachige Inschrift Šābuhrs I. an der Ka ba-i Zardušt (̌̌KZ) (Corpus Inscriptionum JAMASP, $\mathrm{H}$ Iranicarum Part III, Pahlavi Inscriptions. Vol I.I), London 1999.

1907 Vendidâd. Avesta Text with Pahlavi Translation and Commentary, and Glossarial Index, 2 vols, Bombay 1907.

JAMASPASANA, J.M

1897-1913 The Pahlavi Texts. Contained in the Codex MK copied in 1322 A. C. by the Scribe MehrÂwân Kầ-khôsrô, 2 vols, Bombay. [Reprinted in one volume, Teherān n.d].

MACKENZIE, D.N.

1989 Kerdir's Inscription: G. HERRMANN - D.N. MACKENZIE - R. Howell (eds.), The Sasanian Rock Reliefs at Naqsh-i Rustam: Naqsh-i Rustam 6, The Triumph of Shapur I (Iranische Denkmaler Lieferung 13, enthaltend Reihe 2, Iranische Felsreliefs I), Berlin 1989, pp. 3572.

MARKWART, J.

1931 G. Messina (ed.), A Catalogue of the Provincial Capitals of Ērānšahr, Rome 1931.

MODI, J.J.

1898 The Cities of Irān as described in the Old Pahlavi treatise of Shatrō-i-Irān: The Journal of NYBERG, H.S. the Bombay Branch of the Royal Asiatic Society XX, no. LIV (1898), pp. 129-163.

1964-1974 A Manual of Pahlavi, I. Texts, Alphabets, Index, Paradigms, Notes and an Introduction, II. Ideograms, Glossary, Abbreviations, Index, Grammatical Survey, Corrigenda to Part I, 2 vols, Wiesbaden 1964-1974.

PAKZAD, F.

2005 Bundahišn. Zoroastrische Kosmogonie und Kosmologie. Band I, Kritische Edition (Ancient Iranian Studies Series 2), Tehran 2005.

SHAKED, SH.

1979 E. YARSHATER (ed.), The Wisdom of the Sasanian Sages (Denkard VI) (Persian Heritage SKJERVØ, P.O. Series 34), Boulder (Colorado) 1979.

2007 A Postscript on "The Seal of a Eunuch in the Sasanian Court": Journal of Inner Asian Art and Archaeology 2 (2007), p. 39.

2011 The Spirit of Zoroastrianism, New Haven - London 2011. 
SUNDERMANN, W.

1973 Mittelpersische und parthische kosmogonische und Parabeltexte der Manichäer (Berliner Turfantexte IV), Berlin 1973.

1981 Mitteliranische manichäische Texte kirchengeschichtlichen Inhalts (Berliner Turfantexte XI), Berlin 1981.

TAVADIA, J.C.

1930 Šãyast-nē-Šāyast. A Pahlavi Text on Religious Customs, Hamburg 1930. 